\title{
Hydroxy-Directed Enantioselective Hydroxyalkylation in the Carbo- cyclic Ring of Indoles
}

\author{
Marc Montesinos-Magraner, ${ }^{\dagger}$ Carlos Vila, ${ }^{\dagger}$ Gonzalo Blay, ${ }^{\dagger}$ Isabel Fernández, ${ }^{\dagger}$ M. Carmen Muñoz, ${ }^{\ddagger}$ José \\ R. Pedro ${ }^{\dagger *}$
}

†Departament de Química Orgànica, Facultat de Química, Universitat de València, Burjassot, 46100, València, Spain. †Departament de Física Aplicada, Universitat Politècnica de València, València, 46022, Spain.

Supporting Information Placeholder
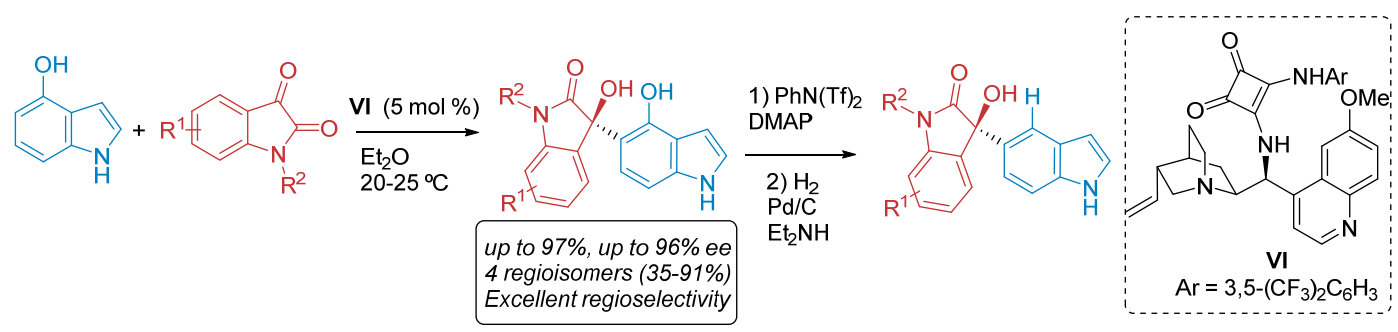

\begin{abstract}
A Cinchona-derived squaramide catalyzes the reaction between hydroxyindoles and isatins leading to enantioenriched indoles substituted in the carbocyclic ring. The reaction proceeds efficiently with differently substituted isatins, yielding the desired products with excellent regioselectivity, good yields and high enantiocontrol. Moreover, every position of the carbocyclic ring of the indole can be functionalize by using the appropriate starting hydroxyindole. The $\mathrm{OH}$ group was removed smoothly upon hydrogenolysis of the corresponding triflate.
\end{abstract}

The ubiquitous presence of the indole moiety, in biologically active molecules and natural occurring compounds, confers this scaffold a distinguished position in organic chemistry. ${ }^{1}$ Accordingly, the enantioselective functionalization of indoles has been one of the most studied reactions in asymmetric catalysis. ${ }^{2}$ Despite the great achievements reached to date, there are still some limitations that must be addressed. One of these limitations is the regioselectivity of the Friedel-Crafts reaction. Indoles show a high nucleophilic reactivity in the azole ring, which is employed in most of the cases to carry out functionalizations in the C-3 position. ${ }^{2}$ Additionally, we can also find different approaches to obtain indoles substituted in the $\mathrm{C}-2$ position, such as the employment of 4,7-dihydroindole and subsequent oxidation. ${ }^{3}$ Finally, under certain reaction conditions, the asymmetric $\mathrm{N}-1$ functionalization of indoles can also be easily achieved. ${ }^{4}$

However, the functionalization of the carbocyclic ring is more difficult. A few methodologies have shown to be successful, although almost exclusively in non-enantioselective procedures. For instance, Iwao and coworkers described in the 90's the directed lithiation of gramines in the $\mathrm{C}-4$ position followed by treatment with nucleophiles such as enals. ${ }^{5 \mathrm{a}, 5 \mathrm{~b}}$ Protected tryptophane derivatives can also be selectively functionalized in the C-4 position using a Pd-catalyzed oxidative coupling, as reported by Jia. ${ }^{5 \mathrm{c}}$ In a similar way, 3 -formyl- $\mathrm{N}$-protected indoles were alkenylated in the $\mathrm{C}-4$ position employing a Ru catalyst. ${ }^{5 \mathrm{~d}}$ The metal-catalyzed borylation of indoles in the $\mathrm{C}-7$ position has also been studied, either using the directed lithiation approach or late-transition metal-catalyzed reactions. ${ }^{5 \mathrm{e}-\mathrm{g}}$ Alternatively, if position $\mathrm{C}-2$ and $\mathrm{C}-3$ are occupied, acid-catalyzed
Friedel-Crafts reactions can take place in the C- 6 position, according to the examples described by You and Shi. ${ }^{5 \mathrm{~h}, 5 \mathrm{ii}}$ Finally, indolines can be used as indole surrogates in C-5 functionalization reactions, as reported by Jørgensen in the enantioselective Friedel-Crafts reactions with glyoxylates and the corresponding imines. ${ }^{6 \mathrm{a}-\mathrm{c}} \mathrm{Yu}$, Movassaghi and coworkers also described the functionalization of indolines in the C-6 positions using a $U$ shaped directing group in the nitrogen. ${ }^{6 \mathrm{~d}}$ These products can easily be converted in the corresponding indoles upon oxidation. In summary, most of these non-asymmetric methods require the presence of directing or blocking group in the azole ring and employ transition metals as catalysts.

Scheme 1. Different approaches for the functionalization of indoles in the carbocyclic ring.

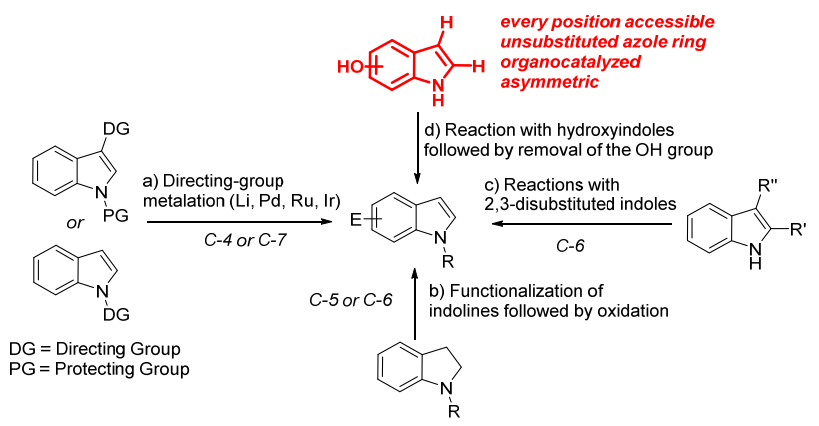

On the other hand, we presented recently an alternative strategy for the functionalization of the carbocyclic ring of indoles 
using an activating/directing group based approach to achieve such a goal, using hydroxyindoles and isatin-derived ketimines as reaction partners. ${ }^{7}$ Hydroxyindoles reacted as phenols under organocatalytic conditions, even when the positions in the azole ring remained unsubstituted. Despite hydroxyindoles have been used to functionalize the carbocyclic ring of indoles in Mannich reactions,${ }^{8}$ this strategy has been scarcely applied to enantioselective processes. ${ }^{9}$ In fact, few examples of hydroxyindoles reacting enantioselectively in the $\mathrm{C}-3$ have been reported. Taking into account the success of our methodology, we aimed to expand the substrate scope. So, we present herein the organocatalytic asymmetric reaction between different hydroxyindoles with isatins, leading to the corresponding enantioenriched 3-hydroxy-3-substituted-2-oxindoles. This scaffold is present in a wide range of natural products and biologically active compounds. ${ }^{10}$ Therefore, several enantioselective arylation reactions have been described using isatins as electrophiles. ${ }^{11}$

We initiated our optimization process screening different bifunctional catalysts in the reaction between 4-hydroxyindole (1a) and $N$-benzylisatin (2a). We were able to obtain the desired 5-alkylated indole 3aa using simple quinine (I) with excellent regioselectivity although in low yield and enantioselectivity (Table 1, entry 1). We could improve the enantiocontrol using differently substituted cupreines (II-IV) (Table 1, entries 2-4), especially when cupreine II, with a benzylic ether in the C-9 position, was used (58\% yield, $88 \%$ ee). Then, we studied related bifunctional catalyst with different $\mathrm{H}$ bond donor groups, such as thiourea $\mathbf{V}$ and squaramide VI (Table 1, entries 5 and 6). These two catalysts gave comparable results, improving the reactivity observed with cupreine II, without compromising the enantioselectivity. We continued by screening different solvents (Table 1, entries 7-12), and $\mathrm{Et}_{2} \mathrm{O}$ led to a slightly better reactivity and enantioselectivity (Table 1 , entry 7 ). With the optimum solvent in hand, we carried out the reaction at different temperatures, obtaining similar results to those obtained at room temperature (Table 1, entries 13-14). Finally, we reduced the catalyst loading to a $5 \mathrm{~mol} \%$ for both catalysts $\mathbf{V}$ and VI (Table 1, entries 15 and 16, respectively). With squaramide $\mathbf{V I} \mathbf{I}^{12}$ we reached $90 \%$ ee with excellent selectivity for the desired product 3aa. Further catalyst loading decrease was detrimental for both yield and enantiocontrol (Table 1, entry 17).

Table 1. Optimization of the reaction conditions. ${ }^{a}$

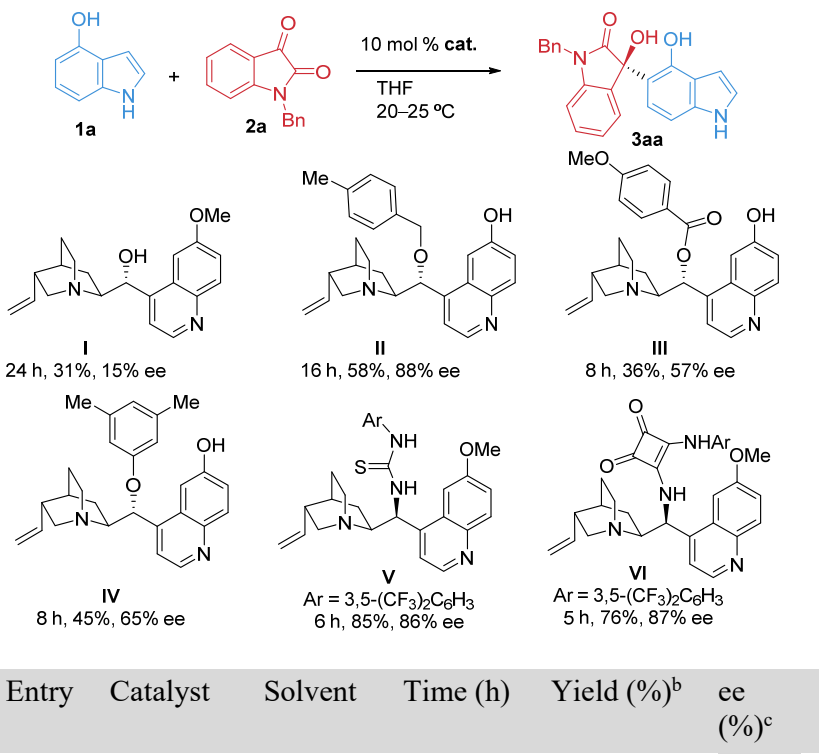

$\begin{array}{llllll}1 & \text { I } & \text { THF } & 24 & 31 & 15 \\ 2 & \text { II } & \text { THF } & 16 & 58 & 88 \\ 3 & \text { III } & \text { THF } & 8 & 36 & 57 \\ 4 & \text { IV } & \text { THF } & 8 & 41 & 65 \\ 5 & \mathbf{V} & \text { THF } & 6 & 85 & 86 \\ 6 & \text { VI } & \text { THF } & 5 & 76 & 87 \\ 7 & \mathbf{V} & \mathrm{Et}_{2} \mathrm{O} & 1 & 83 & 87 \\ 8 & \mathbf{V} & \text { toluene } & 2 & 96 & 66 \\ 9 & \mathbf{V} & \mathrm{CH}_{2} \mathrm{Cl} 2 & 2 & 67 & 73 \\ 10 & \mathbf{V} & \mathrm{EtOAc}_{2} & 3 & 79 & 84 \\ 11 & \mathbf{V} & i \mathrm{Pr}_{2} \mathrm{O} & 3 & 91 & 60 \\ 12 & \mathbf{V} & \operatorname{dioxane} & 18 & 63 & 81 \\ 13^{\mathrm{d}} & \mathbf{V} & \mathrm{Et}_{2} \mathrm{O} & 5 & 94 & 87 \\ 14^{\mathrm{e}} & \mathbf{V} & \mathrm{Et}_{2} \mathrm{O} & 1 & 96 & 88 \\ 15^{\mathrm{f}} & \mathbf{V} & \mathrm{Et}_{2} \mathrm{O} & 4 & 80 & 89 \\ 16^{\mathrm{f}} & \mathbf{V I} & \mathrm{Et}_{2} \mathrm{O} & 4 & 91 & 90 \\ 17^{\mathrm{g}} & \mathbf{V I} & \mathrm{Et}_{2} \mathrm{O} & 7 & 86 & 85\end{array}$

Reaction conditions: 1a $(0.1 \mathrm{mmol}), \mathbf{2 a}(0.1 \mathrm{mmol})$, catalyst $(10$ $\mathrm{mol} \%)$ and solvent $(1.5 \mathrm{~mL})$ at $20-25^{\circ} \mathrm{C}^{\text {b }}$ Isolated yields after column chromatography. $>20: 1$ regioselectivity determined by ${ }^{1} \mathrm{H}$ NMR..$^{c}$ Enantiomeric excess (ee) was determined by chiral HPLC. ${ }^{d}$ Reaction performed at $0^{\circ} \mathrm{C}$. ${ }^{\text {e }}$ Reaction performed at $35^{\circ} \mathrm{C}$. ${ }^{\mathrm{f}} 5 \mathrm{~mol}$ $\%$ cat. loading. ${ }^{\mathrm{g}} 2 \mathrm{~mol} \%$ cat. loading.

Next, we applied these conditions to the reaction between 4hydroxyindole (1a) and different isatins (2,4 and 6). Differently substituted isatins in the aromatic ring can be used under our conditions with excellent regioselectivity and high enantiocontrol. Isatin with a free $\mathrm{NH}$ group can be also used providing the desired alkylated products in moderate ${ }^{13}$ to good yields and good enantioselectivities (50-70\% yield and $78-85 \%$ ee), although the regioselectivity is slightly lower. $N$-Methylisatin is a suitable electrophile for this transformation and compound 7aa was obtained with good results.

Scheme 2. Scope for the enantioselective Friedel-Crafts reaction between hydroxyindole $1 \mathrm{a}$ and differently substituted isatins ${ }^{\mathrm{a}}$

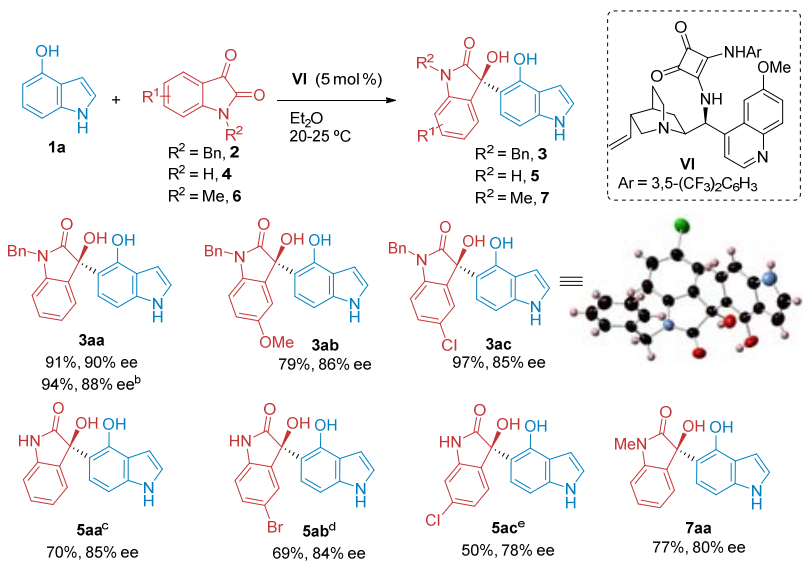

${ }^{a}$ Reaction conditions: 1a $(0.1 \mathrm{mmol}), \mathbf{2 , 4}$ or $\mathbf{6}(0.1 \mathrm{mmol}), \mathbf{V I}$ $(5 \mathrm{~mol} \%)$ in $\mathrm{Et}_{2} \mathrm{O}(1.5 \mathrm{~mL})$ at $20-25^{\circ} \mathrm{C}$. Isolated yields after column chromatography. $>20: 1$ regioselectivity determined by ${ }^{1} \mathrm{H}$ NMR. Enantiomeric excess (ee) was determined by chiral HPLC. ${ }^{b}$ 1 mmol scale reaction. ${ }^{\mathrm{c}}$ 14:1 o:p regioselectivity determined by ${ }^{1} \mathrm{H}$ 
NMR. ${ }^{d}$ 15:1 o:p regioselectivity determined by ${ }^{1} \mathrm{H}$ NMR. ${ }^{\mathrm{e}}$ 10:1 $o: p$ regioselectivity determined by ${ }^{1} \mathrm{H}$ NMR.

In order to prove our methodology is useful for the functionalization of indoles in every position of the carbocyclic ring, we continued our research studying the reaction of 5-hydroxyindole (1b) and differently substituted isatins. As we expected, the corresponding 4-alkylated indoles were isolated with excellent regioselectivity in all cases. Moderate to high yields (52$88 \%)$ and excellent enantioselectivities $(85-96 \%$ ee) were reached regardless of the position of the substituents in the aromatic ring or even in the absence of the benzylic protecting group of the isatin. Unfortunately, 6-hydroxyindole showed low reactivity under the optimized reaction conditions. ${ }^{13}$ Despite the low yield, 7-alkylated product $\mathbf{3 c a}$ was obtained with complete regioselectivity and excellent enantioselectivity $(91 \%$ ee). In contrast, when we tried the reaction with 7-hydroxyindole, the 6-alkylated product 3da was isolated in moderate yield (61\%) and high enantioselectivity ( $86 \%$ ee). Then, we expanded the scope of this transformation to 4-hydroxycarbazole (2e). The desired 3-substituted compound 3ea was obtained with complete regioselectivity and moderate yield and enantioselectivity.

Scheme 3. Scope for the enantioselective Friedel-Crafts reaction between hydroxyindoles 1 and differently substituted isatins $^{\mathrm{a}}$
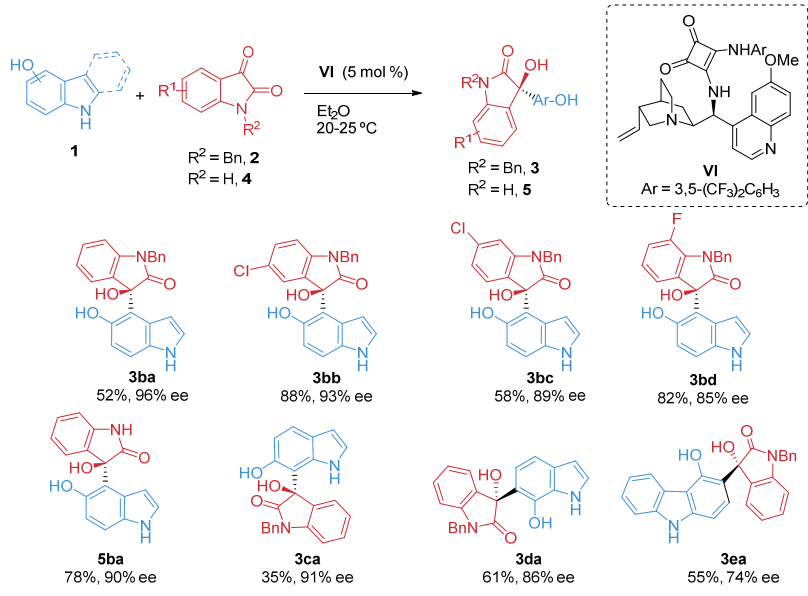

a Reaction conditions: $\mathbf{1}(0.1 \mathrm{mmol}), \mathbf{2}$ or $\mathbf{4}(0.1 \mathrm{mmol}), \mathbf{V I}(5$ $\mathrm{mol} \%)$ in $\mathrm{Et}_{2} \mathrm{O}(1.5 \mathrm{~mL})$ at $20-25^{\circ} \mathrm{C}$. Isolated yields after column chromatography. $>20: 1$ regioselectivity determined by ${ }^{1} \mathrm{H}$ NMR. Enantiomeric excess (ee) was determined by chiral HPLC.

In order to study the scope of the reaction, we also applied our optimized conditions to the reaction of hydroxyindol and carbazole with ethyl trifluoropyruvate $(\mathbf{8})$. This electrophile has been extensively studied in enantioselective Friedel-Crafts reactions, ${ }^{14}$ leading to chiral benzylic tertiary alcohols bearing a trifluoromehtyl group which are of interest in medicinal chemistry. Unfortunately, ethyl trifluoropyruvate showed high reactivity and the C-3 alkylated indole $9 \mathbf{a}^{\prime}$ was isolated as the only reaction product in a racemic form. Further attempts to obtain compound 9a lowering the temperature were unsuccessful. In contrast, 4-hydroxycarbazole reacted with ethyl trifluoropyruvate under our optimized conditions to afford the expected product 9e in 70\% yield and excellent enantioselectivity (98\% ee). These results imply that a fine balance between the reactivity of the three reaction partners is required.

Scheme 4. Friedel-Crafts reactions with ethyl trifluoropyruvate $(8)$.

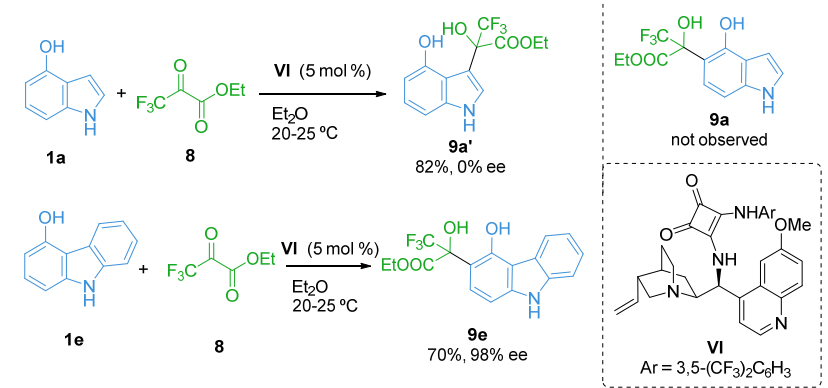

${ }^{a}$ Reaction conditions: $1(0.1 \mathrm{mmol}), \mathbf{8}(0.1 \mathrm{mmol}), \mathbf{V I}(5 \mathrm{~mol} \%)$ in $\mathrm{Et}_{2} \mathrm{O}(1.5 \mathrm{~mL})$ at $20-25{ }^{\circ} \mathrm{C}$. Isolated yields after column chromatography. Enantiomeric excess (ee) was determined by chiral HPLC.

Regardless of the evident importance of highly substituted enantioenriched hydroxyindoles, we performed the removal of the $\mathrm{OH}$ group under mild conditions. For that, we transformed compound 3aa in the corresponding monotriflate and this intermediate product was subjected to Pd-catalyzed hydrogenolysis (1 atm) to obtain the free 5 -substituted indole 10aa in high overall yield and with a slightly erosion of the optical purity. ${ }^{15}$

Scheme 5. Removal of the hydroxy group in product 3aa. ${ }^{a}$

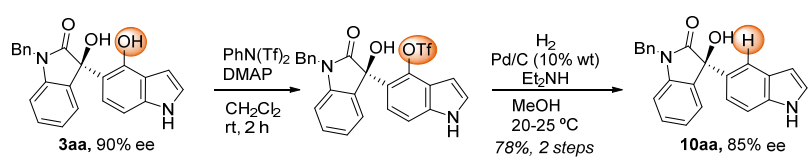

${ }^{\text {aS }}$ See Supporting Information for reaction conditions.

The absolute configuration of compound 3ac was ascertained to be $R$ on the basis of X-ray crystal analysis (See Scheme 2). The configuration of the rest of the products were assigned assuming a uniform stereochemical mechanism. This absolute configuration is the result of an attach of the hydroxyindole to the $R e$ face of the isatin and can be explained by a tertiary complex formed by both reactants and the catalyst. ${ }^{16}$ The stereochemical outcome is in agreement with previously reported enantioselective organocatalyzed reactions with hydroxyarenes. ${ }^{17}$

In conclusion, we present the first enantio- and regioselective hydroxyalkylation in the carbocyclic ring of indoles. We take advantage of the directing and activating properties of the $\mathrm{OH}$ group, by using the four regioisomeric hydroxyindoles as nucleophiles. These hydroxyindoles were reacted with isatins under organocatalytic conditions to afford the corresponding indoles bearing a highly substituted tertiary alcohol in the homoaromatic ring with good yields and high enantiocontrol. We have also varied the substituent in the aromatic ring or the nitrogen in the isatin moiety obtaining good results. Moreover, by employing the appropriate starting hydroxyindole, we can functionalize regioselective every position of the carbocyclic ring of the indole. Finally, the $\mathrm{OH}$ group can be removed easily under mild reductive elimination conditions of the corresponding monotriflate without affecting to the optical purity.

\section{ASSOCIATED CONTENT}

\section{Supporting Information}

The Supporting Information is available free of charge on the ACS Publications website. X-ray data for 3ac (CIF). Complete experimental procedures and characterization of new products, ${ }^{1} \mathrm{H}$ and ${ }^{13} \mathrm{C}$ NMR spectra, and HPLC chromatograms.

\section{AUTHOR INFORMATION}




\section{Corresponding Author}

*jose.r.pedro@uv.es

\section{Notes}

The authors declare no competing financial interest.

\section{ACKNOWLEDGMENT}

Financial support from MINECO (Gobierno de España; CTQ201347494-P) and from Generalitat Valenciana (ISIC2012/001) is gratefully acknowledged. M.M-M. thanks Universitat de València for a pre-doctoral grant and C.V. thanks MINECO for a JdC contract. Access to NMR and MS facilities from the Servei Central de Suport a la Investigació Experimental (SCSIE)-UV is also acknowledged.

\section{REFERENCES}

1 (a) Indoles; Sundberg, R. J. Academic Press: San Diego, 1996. (b) Heterocycles in Life and Society: An Introduction to Heterocyclic Chemistry, Biochemistry and Applications; Pozharskii, A. F.; Soldatenkov, A.; Katritzky, A. R.; John Wiley \& Sons: Chichester, 2011. (c) Zhang, M. Z.; Chen, Q.; Yang, G.-F. Eur. J. Med. Chem. 2015, 89, 421-441. (c) Sherer, C.; Snape, T. J. Eur. J. Med. Chem. 2015, 97, 552-560. (d) Lancianesi, S.; Palmieri, A.; Petrini, M. Chem. Rev. 2014, 114, 7108-7149. (e) Ishikura, M.; Abe, T.; Choshi, T.; Hibino, S. Nat. Prod. Rep. 2015, 32, 1389-1471.

2 For selected reviews: (a) Catalytic Asymmetric Friedel-Crafts Alkylations; Bandini, M.; Umani-Ronchi, A.; Wiley-VCH: Weinheim, 2009. (b) Jørgensen, K. A. Synthesis 2003. 1117-1125. (c) Bandini, M.; Melloni, A.; Umani-Ronchi, A. Angew. Chem., Int. Ed. 2004, 43, 550-556. (d) Poulsen, T. B.; Jørgensen, K. A. Chem. Rev. 2008, 108, 2903-2915. (e) You, S.-L.; Cai, Q.; Zeng, M. Chem. Soc. Rev. 2009, 38, 2190-2201. (f) Bandini, M.; Eichlolzer, A. Angew. Chem. Int. Ed. 2009, 48, 9608-9644. (g) You, S.-L. Cai, Q.; Zeng, M. Chem. Soc. Rev. 2009, 38, 2190-2201. (h) Bartoli, G.; Bencivenni, G.; Dalpozzo, R. Chem. Soc. Rev. 2010, 39, 4449-4465. (i) Dalpozzo, R. Chem. Soc. Rev. 2015, 44, 742-778.

3 (a) Evans, D. A.; Fandrick, K. R. Org. Lett. 2006, 8, 2249-2252. (b) Evans, D. A.; Fandrick, K. R.; Song, H.-Ji; Scheidt, K. A.; Xu, Ri. J. Am. Chem. Soc. 2007, 129, 10029-10041. (c) Blay, G.; Fernández, I.; Pedro, J. R.; Vila, C. Tetrahedron Lett. 2007, 48, 67316734. (d) Kang, Q.; Zheng, X.-J.; You, S.-L. Chem. Eur. J. 2008, 14, 3539-3542. (e) Hong, L.; Liu, C.; Sun, W.; Wang, L.; Wong, K.; Wang, R. Org. Lett. 2009, 11, 2177-2180. (f) Sheng, Y.-F.; Li, G.Q.; Kang, Q.; Zhang, A.-J.; You, S.-L. Chem. Eur. J. 2009, 15, 33513354. (g) Wang, T.; Zhang, G.-W.; Teng, Y.; Nie, J.; Zheng, Y.; Ma, J.-A. Adv. Synth. Catal. 2010, 352, 2773-2777. (h) Blay, G.; Fernández, I.; Muñoz, M. C.; Pedro, J. R.; Recuenco, A.; Vila, C. J. Org. Chem. 2011, 76, 6286-6294.

4 (a) Cui, H.-L.; Feng, X.; Peng, J.; Lei, J.; Jiang, K.; Chen, Y.C. Angew. Chem., Int. Ed. 2009, 48, 5737-5740. (b) Stanley, L. M.; Hartwig, John F. Angew. Chem., Int. Ed. 2009, 48, 7841-7844. (c) Trost, B. M.; Osipov, M.; Dong, G. J. Am. Chem. Soc. 2010, 132, 15800-15807. (d) Xie, Y.; Zhao, Y.; Qian, B.; Yang, L.; Xia, C.; Huang, H. Angew. Chem., Int. Ed. 2011, 50, 5682-5686. (e) Cheng, H.-G.; Lu, L.-Q.; Wang, T.; Yang, Q.-Q.; Liu, X.-P.; Li, Y.; Deng, Q.-H.; Chen, J.-R.; Xiao, W.-J. Angew. Chem., Int. Ed. 2013, 5, 3250-3254. (f) Sevov, C. S.; Zhou, J.; Hartwig, J. F. J. Am. Chem. Soc. 2014, 136, 3200-3207. (g) Bera, K.; Schneider, C. Org. Lett. 2016, 18, 5660-5663.

5 (a) Iwao, M.; Ishibashi, F. Tetrahedron 1997, 53, 51-58. (b) Fukuda, T.; Maeda, R.; Iwao, M. Tetrahedron 1999, 55, 9151-9162. (c) Liu, Q.; Li, Q.; Ma, Y.; Jia, Y. Org. Lett. 2013, 15, 4528-4531. (d) Lanke, V.; Ramaiah Prabhu, K. Org. Lett. 2013, 15, 6262-6265. (e) Hartung, C. G.; Fecher, A.; Chapell, B.; Snieckus, V. Org. Lett. 2003, 5, 1899-1902. (f) Paul, S. A.; Chotana, G. A.; Holmes, D.; Reichle, R. C.; Maleczka, R. E.; Smith, M. R. J. Am. Chem. Soc. 2006, 128, 15552-15553. (g) Robbins, D. W.; Boebel, T. A.; Hartwig, J. F. J. Am. Chem. Soc. 2010, 132, 4068-4069. (h) Liu, H.; Zheng, C.; You, S.-L. J. Org. Chem. 2014, 79, 1047-1054. (i) Zhou,
L.-J.; Zhang, Y.-C.; Zhao, J.-J.; Shi, F.; Tu, S.-J. J. Org. Chem. 2014, 79, 10390-10398

6 (a) Gathergood, N.; Zhuang, W.; Jørgensen, K. A. J. Am. Chem. Soc. 2000, 122, 12517-12522. (b) Saaby, S.; Fang, X.; Gathergood, N.; Jørgensen, K. A. Angew. Chem. Int. Ed. 2000, 39, 4114-4116. (c) Zhuang, W.; Gathergood, N.; Hazell, R. G.; Jørgensen, K. A. J. Org. Chem. 2001, 66, 1009-1013. (d) Yang, G.; Lindovska, P.; Zhu, D.; Kim, J.; Wang, P.; Tang, R.-Y.; Movassaghi, M.; Yu, J.-Q. J. Am. Chem. Soc. 2014, 136, 10807-10813.

7 Montesinos-Magraner, M.; Vila, C.; Rendón-Patiño, A.; Blay, G.; Fernández, I.; Muñoz, M. C.; Pedro, J. R. ACS Catal. 2016, 6, 2689-2693.

8 (a) Monti, S. A.; Johnson, W. O.; White, D. H. Tetrahedron Lett. 1966, 7, 4459-4464. (b) Troxler, F.; Bormann, G.; Seemann, F. Helv. Chim. Acta 1968, 51, 1203-1213. (c) Monti, S. A.; Johnson, W. O. Tetrahedron 1970, 26, 3685-3694.

9 (a) Jørgensen et al. have described a single example of the 1,6Friedel-Crafts/1,4-oxa-Michael reaction with 4-hydroxyindole (7 days; $43 \%$ yield, 97\% ee). Poulsen, P. H.; Feu, K. S.; Paz, B. M.; Jensen, F.; Jørgensen, K. A. Angew. Chem., Int. Ed. 2015, 54, 82038207. (b) Jia, Y.-X.; Zhong, J.; Zhu, S.-F.; Zhang, C.-M.; Zhou, Q.L. Angew. Chem. Int. Ed. 2007, 46, 5565-5567. (c) Wolf, C.; Zhang, P. Adv. Synth. Catal. 2011, 353, 760-766. (d) Saha, S.; Alamsetti, S. K.; Schneider, C. Chem. Commun. 2015, 51, 1461-1464.

10 (a) Takayama, H.; Shimizu, T.; Sada, H.; Harada, Y.; Kitajima, M.; Aimi, N. Tetrahedron 1999, 55, 6841-6846. (b) Singh, S. B.; Jayasuriya, H.; Salituro, G. M.; Zink, D. L.; Shafiee, A.; Heimbuch, B.; Silverman, K. C.; Lingham, R. B.; Genilloud, O.; Teran, A.; Vilella, D.; Felock, P.; Hazuda, D. J. Nat. Prod. 2001, 64, 874-882. (c) Lin, S.; Yang, Z.; Kwok, B. H. B.; Koldobskiy, M.; Crews, C. M.; J. Am. Chem. Soc. 2004, 126, 6347-6355. (d) Suzuki, H.; Morita, H.; Shiro, M.; Kobayashi, J. Tetrahedron 2004, 60, 2489-2495. (e) Kagata, T.; Saito, S.; Shigemori, H.; Ohsaki, A.; Ishiyama, H.; Kubota, T.; Kobayashi, J. J. Nat. Prod. 2006, 69, 1517-1521.

11 For selected reviews: (a) Zhou, F.; Liu, Y.-L.; Zhou, J. Adv. Synth. Catal. 2010, 352, 1381-1407. (b) Y, R.; Bartoli, G.; Bencivenni, G. Chem. Soc. Rev. 2012, 41, 7247-7290. (c) Yu, B.; Xing, H.; Yu, D.-Q.; Liu, H.-M. Beilstein J. Org. Chem. 2016, 12, 1000-1039. For selected enantioselective arylation of isatins: (d) Shintani, R.; Inoue, M.; Hayashi, T.; Angew. Chem. Int. Ed. 2006, 45, 3353-3356. (e) Toullec, P. Y. ; Jagt, R. B. C.; de Vries, J. G. ; Feringa, B. L.; Minnaard, A. J. Org. Lett. 2006, 8, 2715-2718. (f) Hanhan, N. V.; Sahin, A. H.; Chang, T. W.; Fettinger, J. C.; Franz, A. K. Angew. Chem. Int. Ed. 2010, 49, 744-747. (g) Chauhan, P.; Chimni, S. S. Chem. Eur. J. 2010, 16, 7709-7713. (h) Gutierrez, E. G.; Wong, C. J.; Sahin, A. H.; Franz, A. K. Org. Lett. 2011, 13, 5754-5757. (i) Chauhan, P.; Chimni, S. S. Tetrahedron Lett. 2013, 54, 4613-4616. (j) Li, C.; Guo, F.; Xu, K.; Zhang, S.; Hu, Y.; Zha, Z.; Wang, Z. Org. Lett. 2014, 16, 3192-3195. (k) Kaur, J.; Kumar, A.; Chimni, S. S. Tetrahedron Lett. 2014, 55, 2138-2141. (1) Wu, D.; Zhang, X.; Xu, Y.; Xue, Y.; Li, J.; Wang, W.; Zhu, J. Asian J. Org. Chem. 2014, 3, 480-486. (m) Kaur, J.; Kumar, A.; Chimni, S. S. Tetrahedron Lett. 2014, 55, 2138-2141. (n) Kaur, J.; Kumar, A.; Chimni, S. S. RSC Adv. 2014, 4, 62367-62374. (o) Kumar, A.; Kaur, J.; Chauhan, P.; Chimni, S. S. Chem. Asian J. 2014, 9, 1305-1310.

12 The lower yields obtained in some cases are due to low reactivity under the optimized reaction conditions.

13 For a seminal report: (a) Malerich, J. P.; Hagihara, K.; Rawal, V. H. J. Am. Chem. Soc. 2008, 130, 14416-14417. For selected reviews: (b) Alemán, J.; Parra, A.; Jiang, H.; Jørgensen, K. A. Chem. Eur. J. 2011, 17, 6890-6899. (c) Storer, R. I.; Aciro, C.; Jones, L. H.; Chem. Soc. Rev. 2011, 40, 2330-2346. (d) Chauhan, P.; Mahajan, S.; Kaya, U.; Hack, D.; Enders, D. Adv. Synth. Catal. 2015, 357, 253-281.

14 For enantioselective Friedel-Crafts reaction with trifluoropyruvates: (a) Török, B.; Abid, M.; London, G.; Esquibel, J.; Török, M.; Mhadgut, S. C.; Yan, P.; Prakash, G. K. S. Angew. Chem. Int. Ed. 2005, 44, 3086-3089. (b) Lyle, M. P. A.; Draper, N. D.; Wilson P. D. Org. Lett. 2005, 7, 901-904. (c) Zhao, J.-L.; Liu, L.; Sui, Y.; Liu, Y.-L.; Wang, D.; Chen, Y.-J. Org. Let. 2006 8, 6127-6130. (d) Zhao, J.-L.; Liu, L.; Gu, C.-L.; Wang, D.; Chen, Y.- 
J. Tetrahedron Lett. 2008, 49, 1476-1479. (e). Nie, J.: Zhang, G.-W.; Wang, L.; Zheng, D.-H.; Zheng, Y.; Ma J.-A.; Eur. J. Org. Chem. 2009, 3145-3149. (f). Montesinos-Magraner, M.; Vila, C.; Blay, G.; Fernández, I.; Muñoz, M. C.; Pedro, J. R. Adv. Synth. Catal. 2015, 357, 3047-3051.

15 Mori, A.; Mizusaki, T. ; Ikawa, T. ; Maegawa, T.; Monguchi Y.; Sajiki, H. Tetrahedron 2007, 63, 1270-1280.
16 Kumari, P.; Barik, S.; Khan, N. H.; Ganguly, B.; Kureshy, R. I.; Abdi, S. H. R.; Bajaj, H. C. RSC Adv. 2015, 5, 69493-69501.

17 Montesinos-Magraner, M.; Vila, C.; Blay, G.; Pedro, J. R. Synthesis 2016, 48, 2151-2164.<smiles>[R20]Oc1ccc2c(c1)C(=O)C(=O)N2[R2]</smiles>
$\mathrm{R}^{2}$ $\mathrm{Et}_{2} \mathrm{O}$
$20-25^{\circ} \mathrm{C}$

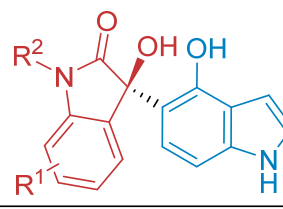

up to $97 \%$, up to $96 \%$ ee

4 regioisomers (35-91\%)

Excellent regioselectivity
1) $\mathrm{PhN}(\mathrm{Tf})_{2}$ DMAP

2) $\mathrm{H}_{2}$ $\mathrm{Pd} / \mathrm{C}$ $\mathrm{Et}_{2} \mathrm{NH}$

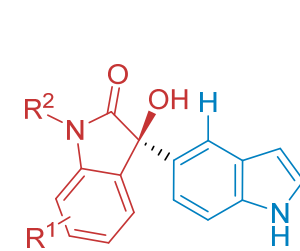
$\mathrm{R}^{11}=\mathrm{H}$

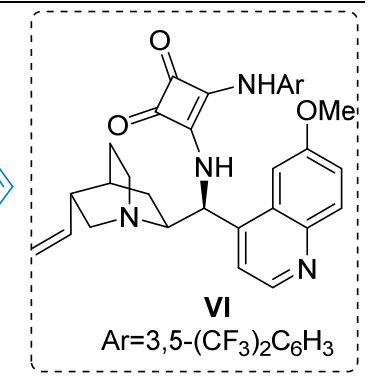

